\title{
Neoplecostomus (Teleostei: Loricariidae) from the upper Rio Paraná basin, Brazil, with description of three new species
}

\author{
CLÁUDIO HENRIQUE ZAWADZKI ${ }^{1}$, CARLA SIMONE PAVANELLI ${ }^{1} \&$ FRANCISCO LANGEANI $^{2}$ \\ ${ }^{1}$ Universidade Estadual de Maringá, Nupélia, Av. Colombo, 5790, 87020-900 Maringá, PR, Brazil. \\ E-mail: chzawadzki@nupelia.uem.br,carlasp@nupelia.uem.br. \\ ${ }^{2}$ Universidade Estadual Paulista, Departamento de Zoologia e Botânica, IBILCE, R. Cristóvão Colombo, 2265, 15054-000 São José \\ do Rio Preto, SP, Brazil.Email: langeani@ibilce.unesp.br.
}

\begin{abstract}
Neoplecostomus paranensis was the only Neoplecostomus species known from the upper Rio Paraná basin, and it was diagnosed from its congeners mainly by the absence or reduction of the adipose fin. In this study we describe three new Neoplecostomus species. All of them are promptly differentiated from N. paranensis by having a well-developed adipose fin. Furthermore, the new species are differentiated from congeners by morphometric and meristic traits, in addition to color pattern. Neoplecostomus paranensis is redescribed. We also provide an identification key to all Neoplecostomus species.
\end{abstract}

Key words: catfishes, freshwater, Neotropical, Ostariophysi, Siluriformes, ichthyology

\section{Resumo}

Neoplecostomus paranensis era a única espécie de Neoplecostomus conhecida na bacia do alto rio Paraná e era diagnosticada de suas congêneres principalmente pela ausência ou redução da nadadeira adiposa. Neste estudo, descrevemos três novas espécies de Neoplecostomus. Todas são prontamente diferenciadas de N. paranensis por apresentar uma nadadeira adiposa bem desenvolvida. Além disso, as espécies novas são diferenciadas das congêneres por caracteres morfométricos e merísticos, além do padrão de colorido. Neoplecostomus paranensis é redescrita. Uma chave para identificação de todas as espécies de Neoplecostomus também é fornecida.

\section{Introduction}

Neoplecostomus was revised by Langeani (1990) who recognized two valid species, $N$. granosus (Valenciennes) from Cayenne (French Guyana) and Rio de Janeiro, and N. microps (Steindachner), type-species of the genus, from the Rio Paraíba do Sul basin, and described four new species from Brazil: N. espiritosantensis, from coastal streams of Espírito Santo State, N. franciscoensis, from headwater streams of Rio São Francisco basin, N. paranensis, from headwater streams of upper Rio Paraná basin (sensu Britski and Langeani 1988), and $N$. ribeirensis, from the Rio Ribeira de Iguape basin. Bizerril (1995) described an additional species, $N$. variipictus from the Rio Paraíba do Sul basin.

Neoplecostomus paranensis, diagnosed by the lack or reduction of adipose fin, is the only species known from the upper Rio Paraná basin to date. In recent years increasing inventory efforts in that basin allowed the recognition of three new Neoplecostomus species, from small tributaries of the Paranaíba, Paranapanema, and Tibagi rivers, upper Rio Paraná basin, which are readily differentiated from $N$. paranensis by having a well- 